\title{
Omeprazole inhibits colorectal carcinogenesis induced by azoxymethane in rats
}

University Departments of Medicine and Therapeutics

I D Penman

E El-Omar

K E L McColl

Surgery

J R McGregor

P J O'Dwyer

and Pathology, Western Infirmary, Glasgow K J Hillan

Correspondence to: Dr I D Penman, University Department of Medicine and Therapeutics, Western Infirmary, Glasgow G11 6NT Accepted for publication 22 February 1993

\section{Abstract}

Numerous clinical and experimental studies suggest that gastrin plays an important part in the development of colorectal cancer in humans. This study was done to assess the influence of omeprazole induced hypergastrinaemia on the development of colorectal tumours in an experimental animal model. Forty female Sprague-Dawley rats received either omeprazole $(40 \mu \mathrm{mol} / \mathrm{kg})$ or vehicle (0.25\% methylcellulose) by once daily oral gavage throughout the experiment. All animals received 12 consecutive weekly subcutaneous injections of azoxymethane (10 $\mathrm{mg} / \mathrm{kg} /$ week) beginning at week 6 . Serum gastrin concentrations were measured during weeks 1 and 5 and at death (week 27). Chronic omeprazole treatment resulted in appreciable hypergastrinaemia during the study, mean gastrin concentrations in omeprazole treated rats being raised by up to nine to $\mathbf{1 0}$ fold, compared with vehicle treated control rats $(p<0.001)$. Despite this, tumour incidence in the omeprazole group was significantly lower at $63 \%$, compared with $95 \%$ in the vehicle only group $(\mathbf{p}<0.02)$. The median number of tumours in the omeprazole group (1) compared with the vehicle group (3) was also significantly lower $(p=0 \cdot 02)$. Average tumour size, site distribution, and the comparative frequencies of adenomas and adenocarcinomas were similar in the two groups. This study shows that omeprazole protects against colorectal carcinogenesis in this model despite causing appreciable hypergastrinaemia. The mechanism by which this occurs is unclear and merits further investigation. Because of the compounding protective effects of omeprazole, this model is not a suitable one for studying the longterm trophic effects of gastrin on the colon.

(Gut 1993; 34: 1559-1565)

Several lines of investigation suggest that gastrin may have important growth stimulating roles in human colorectal cancer. The hormone is trophic for the colonic epithelium in rodents ${ }^{1}$ and also stimulates proliferation of normal and malignant colonic epithelial cells in vitro. ${ }^{23}$ In addition, gastrin enhances the growth of colonic tumour xenografts in nude mice resulting in their reduced survival, ${ }^{4}$ an effect which can be inhibited by the gastrin receptor antagonist proglumide. ${ }^{5}$ Subsequently, newer and more specific antagonists have been developed and these can also inhibit the trophic effects of gastrin on colorectal tumour cells. ${ }^{67}$ Furthermore, specific, high affinity gastrin receptors have been shown on both normal and malignant colonic epithelium ${ }^{89}$ as well as on a significant proportion of primary human colorectal tumours. ${ }^{10}$ In animal models of colorectal cancer, hypergastrinaemia produced endogenously by either antral exclusion or small bowel resection, or by pentagastrin injections, has been found to enhance the development of tumours induced by either azoxymethane or dimethylhydrazine. ${ }^{11-13}$ It has to be stated, however, that not all authors have been able to show a trophic effect of gastrin in the colon, either in vitro ${ }^{14}$ is or in vivo ${ }^{16}$ and others have found gastrin to have no promoting effect on chemical carcinogenesis in rodents. ${ }^{17}$ In addition, Graffner $e t a l^{18}$ found that omeprazole induced hypergastrinaemia had no promoting effect on the growth of established colonic tumours growing as xenografts in mice. Thus, in vitro studies and animal models of colonic cancer have not yet conclusively shown an important role for gastrin.

Numerous studies have reported raised gastrin concentrations in patients with colonic tumours, compared with control patients ${ }^{19-21}$ and the concentration may fall after successful treatment, suggesting that the tumour secretes either gastrin or a gastrin releasing peptide. In addition, some human tumours synthesise gastrin $\mathrm{mRNA}^{23}$ or contain immunoreactive gastrin, ${ }^{24}$ and it is therefore possible that gastrin may possess autocrine as well as endocrine trophic roles in this condition.

Hypergastrinaemia also occurs during treatment with the now widely used $\mathrm{H}+/ \mathrm{K}+$ ATPase inhibitor omeprazole. ${ }^{25}$ The hypergastrinaemia is thought to be secondary to its profound inhibitory effects on gastric acid secretion and is probably the mechanism underlying the development of enterochromaffin like cell (ECL cell) carcinoid tumours seen in rats after prolonged treatment with omeprazole and other acid inhibitory drugs. ${ }^{26}$ Omeprazole induced hypergastrinaemia has also been shown to stimulate proliferation of rat colonic mucosa in vivo ${ }^{27}$ and for these reasons, concerns have been raised over the longterm safety of this drug.

To assess further the role of gastrin in colorectal carcinogenesis we have examined the effect of endogenous hypergastrinaemia produced by omeprazole on the development of colorectal tumours induced in rats by azoxymethane.

\section{Materials and methods}

\section{ANIMALS}

Forty five week old female Sprague-Dawley rats (Harlan OLAC Ltd, UK) weighing 125-150 g were used. The animals were housed in cages with controlled temperature $\left((\mathrm{SD}) 21(1)^{\circ} \mathrm{C}\right)$, humidity (50 (5)\%) and light cycle (12 hour). Normal tap water and standard laboratory diet 
(Bantin and Kingman Ltd, Hull, UK) were fed ad libitum.

\section{EXPERIMENTAL DESIGN}

After one week of acclimatisation, animals were randomly divided into two groups and dosed once daily by oral gavage with either omeprazole, $40 \mu \mathrm{mol} / \mathrm{kg}$ (at a volume of $5 \mathrm{ml} / \mathrm{kg}$ ) or vehicle (buffered methylcellulose) for the entire 27 weeks of the study. In addition all animals received 12 weekly subcutaneous injections of azoxymethane $10 \mathrm{mg} / \mathrm{kg}$ (total dose $=120 \mathrm{mg} / \mathrm{kg}$ ) beginning in week 6 . Food intake for each group was calculated during weeks $10,14,16,21$, and 24 . Animals were inspected and weighed three times weekly after carcinogen treatment and killed if they showed signs of tumour development such as abdominal distension, rectal bleeding, or weight loss of $10 \%$ or more. All other survivors were killed in week 27, by exsanguination under $\mathrm{CO}_{2}$ anaesthesia.

\section{GASTRIN ANALYSIS}

Samples of tail vein blood $(0.7 \mathrm{ml})$ were taken and serum separated for gastrin measurement in six freely fed rats from each group at the start of the study (before beginning treatment with either omeprazole or vehicle) and in all animals at death. At the end of the study, blood was taken from omeprazole treated rats either four hours $(n=6)$ or 24 hours $(n=13)$ after the last dose of omeprazole. All blood sampling was done between 1200 and 1600 to minimise the possible effects of diurnal variation in gastrin concentrations. Additionally, in week 5, before starting azoxymethane injections, blood was taken from three animals in each group at four hour intervals throughout a 24 hour period to assess not only the degree but also the duration of hypergastrinaemia (different rats were bled at each time point).

Gastrin was measured in $200 \mu \mathrm{l}$ of serum by radioimmunoassay using antibody $\mathrm{R} 98$, as previously published.$^{28}$ This antibody recognises the $C$ terminal end of both human and rat gastrin and has a sensitivity of $5 \mathrm{ng} / \mathrm{l}$.

\section{NECROPSY ANALYSIS}

All animals were killed between 1200 and 1600 . At death, all animals had a necropsy and the viscera were carefully examined. After division of the pubic symphisis the entire colon from anorectal junction to caecum was excised, opened lengthwise, and pinned flat on a cork mat. Colon length was measured and the number, position (in $\mathrm{mm}$ from the anorectal junction), and volumes (product of

TABLE I Calculated food consumption per group measured at five time points during the experimental period

\begin{tabular}{llllll}
\hline Group & $W k 10$ & $W k 14$ & $W k 16$ & $W k 21$ & $W k 24$ \\
\hline Omeprazole & $18 \cdot 2(0 \cdot 9)^{\star}$ & $19 \cdot 8(1 \cdot 4)^{\star \star}$ & $19 \cdot 0(1 \cdot 4)$ & $19 \cdot 7(1 \cdot 0)$ & $19 \cdot 5(2 \cdot 0)$ \\
Vehicle & $17 \cdot 1(1 \cdot 2)$ & $16 \cdot 6(0 \cdot 8)$ & $19 \cdot 9(0 \cdot 7)$ & $22 \cdot 8(1 \cdot 6)^{\star \star}$ & $18 \cdot 7(2 \cdot 5)$ \\
\hline
\end{tabular}

${ }^{\star} \mathrm{p}<0 \cdot 05,{ }^{\star \star} \mathrm{p}<0 \cdot 001$. Results are expressed as grams/rat/day (mean (SD)). length $\times$ width $\times$ depth in $\mathrm{mm}^{3}$ ) of all macroscopically visible lesions recorded. The liver was sliced at 2-3 mm intervals to assess the presence of metastasis. After overnight fixation in 10\% neutral buffered formalin, all lesions were removed, individually coded, processed, and embedded in paraffin wax. In addition, samples of liver as well as macroscopically normal ascending and descending colon (from $25 \%$ and $75 \%$ along the length of the colon) were taken for detailed histopathological analysis. Sections ( $4 \mu \mathrm{m}$ thick) were stained with haematoxylin and eosin and examined without knowledge of their group of origin. All neoplastic lesions were classified as either benign adenomas or adenocarcinomas. ${ }^{29}$

\section{CHEMICALS}

Pure omeprazole (Dr H Mattsson, Astra Hässle) was suspended in $0 \cdot 25 \%$ methylcellulose (Dow Chemicals), buffered with $2 \mathrm{mg} / \mathrm{ml}$ sodium bicarbonate, and adjusted to $\mathrm{pH} 9.0$ with sodium hydroxide. The solution was stored at $-20^{\circ} \mathrm{C}$ before use and fresh aliquots thawed for use every four to five days and kept at $4^{\circ} \mathrm{C}$. Azoxymethane (Sigma Chemical Co, Dorset, UK) was dissolved in sterile $0.9 \%$ sodium chloride, kept as a stock solution of $100 \mathrm{mg} / \mathrm{ml}$ at $4^{\circ} \mathrm{C}$ and further diluted to a final concentration of $10 \mathrm{mg} /$ $\mathrm{ml}$ with sodium chloride immediately before use.

\section{Statistical analysis}

All statistical testing was performed using the statistical software package MINITAB 8.0 (Minitab Inc, USA). Tumour incidence was analysed by Fisher's exact test and tumour distribution and multiplicity by the MannWhitney $U$ test. Correlations between animal weight and tumour development were assessed using Spearman's rank correlation coefficient. Student's unpaired $t$ test was used for all other tests including tumour volumes after logarithmic transformation of the data. Statistical significance was taken as a value of $p<0.05$ in all tests.

\section{Results}

ANIMAL GROWTH AND WELLBEING

Both groups of animals grew at similar rates, although by the end of the study the omeprazole treated rats were on average $12 \%$ lighter, with a mean weight (SD) of 343 (42) $\mathrm{g}$ compared with 391 (48) $\mathrm{g}$ in the placebo group $(\mathrm{p}<0.005)$. Despite this, calculated food consumption (Table I) was found to be significantly higher in weeks $10(\mathrm{p}<0.05)$ and $14(\mathrm{p}<0.001)$ in the omeprazole group, similar in weeks 16 and 24 , and only higher in the vehicle group during week $21(\mathrm{p}<0 \cdot 001)$.

All animals surviving beyond week 21 (when the first tumour developed) were included in effective numbers for analysis. One rat in the omeprazole group died during week 10 after oesophageal perforation at oral gavage and was therefore excluded. Two rats in the vehicle treated group developed tumours in week 25 but all other animals survived until the end of the study in week 27 . 


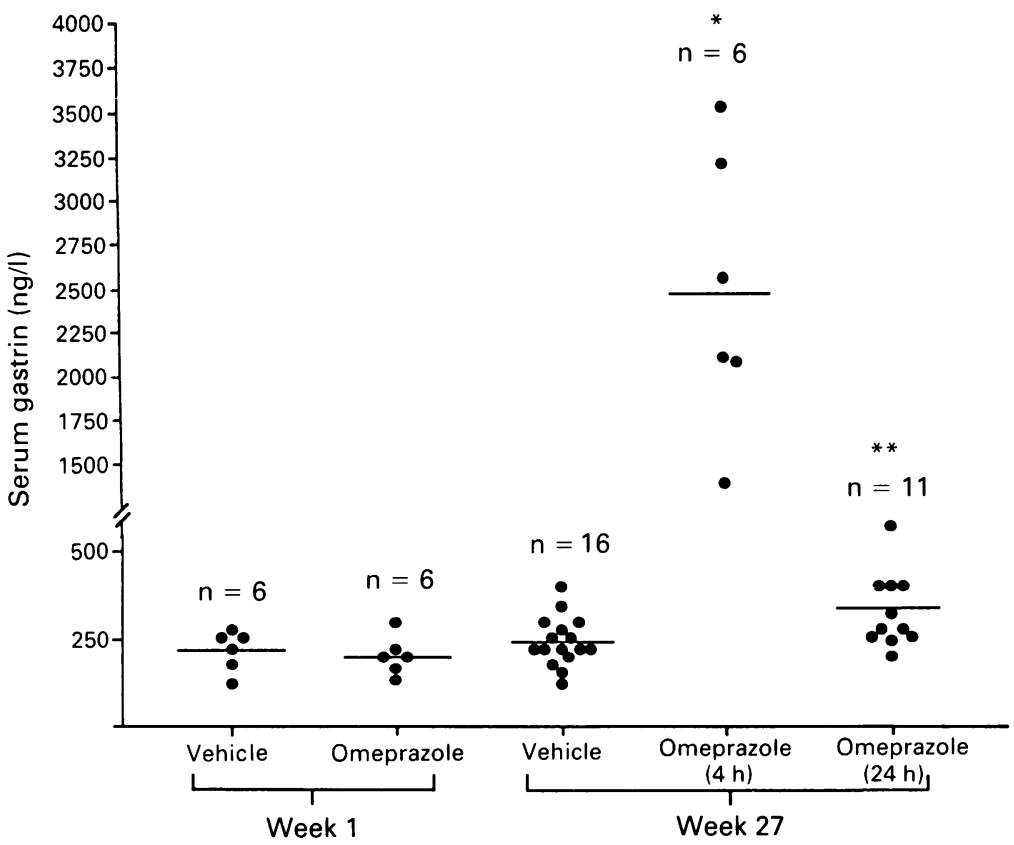

Figure 1: Serum gastrin concentrations during week 1 and week 27 in both groups. Horizontal bars and numbers represent mean values. Note that the y axis is interrupted between 500 and $1500 \mathrm{ng} / \mathrm{l}$. Values for only 11 omeprazole rats are shown 24 hours after the final dose, two samples being unsuitable for analysis. ${ }^{\star} p=0.001,{ }^{\star}{ }^{*} p<0.05$ compared with vehicle treated rats. the gastrin concentrations 24 hours after the last dose (range 200-600 ng/l).

The serum gastrin profiles performed during week 5 of the study confirmed that omeprazole treatment resulted in raised gastrin concentrations throughout most of the 24 hour period (Fig 2). Peak values occurred two hours after dosing (1700 ng/l, about ninefold increase) and even 24 hours after omeprazole (that is, before the next dose), the mean gastrin value was about twice that in the vehicle group ( $383 \mathrm{ng} / \mathrm{l}$ and $184 \mathrm{ng} / \mathrm{l}$, respectively)

TUMOUR DEVELOPMENT

Significantly fewer rats in the omeprazole treated group $(12 / 19,63 \%)$ developed histologically confirmed tumours, compared with the rats treated with vehicle only $(19 / 20,95 \%) ; p<0.02$ (Table II). Furthermore, in the omeprazole group, both the total number of tumours (28) and the median number of tumours per rat $(1 \cdot 0$, range $0-5)$ were significantly lower $(p=0.02)$ than in the vehicle treated group (59 tumours, median 3.0 , range $0 \cdot 10)$. Close examination of sections taken from samples of macroscopically normal ascending and descending colon did not show any early or microscopic lesions. Liver metastases were not found in either group but deposits of tumour were seen in the omentum of one rat in the vehicle treated group. The comparative numbers of benign adenomas and adenocarcinomas were similar in both groups and there was no significant difference between the groups in the site distribution of the tumours, most occurring in the distal colon and rectum in each group (Fig 3 ).

There was no significant difference in average tumour size in the two groups as measured by the median tumour volume (Fig 4), the results being $30 \mathrm{~mm}^{3}$ (vehicle) and $27 \mathrm{~mm}^{3}$ (omeprazole). There was, however, a preponderance of small tumours $\left(<10 \mathrm{~mm}^{3}\right)$ in the vehicle group $(22 / 59$, $37 \%)$, compared with the omeprazole group $(4 / 28,14 \%)$ although the reason for this is unclear (see Discussion).

\section{Discussion}

The aim of this study was to assess whether persistent endogenous hypergastrinaemia secondary to prolonged omeprazole treatment would enhance colorectal carcinogenesis induced in rats by azoxymethane. Despite causing appreciable hypergastrinaemia (concentrations raised up to 10 -fold) the results show that, contrary with our hypothesis, chronic omeprazole treatment significantly inhibited tumour formation. There are several possible explanations for our findings.

Firstly, it is possible that omeprazole treated rats developed tumours with similar frequency but that the drug inhibited their growth, resulting in many microscopic lesions being missed in the omeprazole group. We feel this is unlikely because the samples of normal flat colon taken from all rats failed to show any early microscopic lesions. Furthermore, if omeprazole inhibited the growth of tumours once they developed, then one would have expected this group to have on average smaller tumours, but this was not the
Figure 2: Serum gastrin concentrations (mean $(S D)$ ) throughout a 24 hour period during week 5. Gastrin was measured in three rats from each group at four hour intervals before and after dosing with either omeprazole or vehicle. 
TABLE II Tumour development

\begin{tabular}{|c|c|c|c|c|c|c|c|}
\hline Group & No & $\begin{array}{l}\text { Tumour } \\
\text { +ve rats }\end{array}$ & $\begin{array}{l}\text { Tumours/ } \\
\text { ratt }\end{array}$ & $\begin{array}{l}\text { Total } \\
\text { tumours/ } \\
\text { group }\end{array}$ & Adenomas & $\begin{array}{l}\text { Adeno- } \\
\text { carcinomas }\end{array}$ & $\begin{array}{l}\text { Rats with } \\
\text { metastasis }\end{array}$ \\
\hline $\begin{array}{l}\text { Omeprazole } \\
\text { Vehicle }\end{array}$ & $\begin{array}{l}19 \\
20\end{array}$ & $\begin{array}{l}12^{\star} \\
19\end{array}$ & $\begin{array}{l}1.0(0.5)^{\star \star} . \\
3.0(0-10)\end{array}$ & $\begin{array}{l}28^{\star \star} \\
59\end{array}$ & $\begin{array}{r}6 \\
11\end{array}$ & $\begin{array}{l}22 \\
48\end{array}$ & $\begin{array}{l}0 \\
1\end{array}$ \\
\hline
\end{tabular}

${ }^{\star} \mathrm{p}<0.02,{ }^{\star \star} \mathrm{p}=0.02$, compared with vehicle treated rats. $\nmid$ Results are medians (ranges).

case. It is possible to speculate, however, that omeprazole may have exerted its effects on tumour initiation by the mechanisms discussed below but that once tumours developed the trophic effects of the raised gastrin concentrations in this group resulted in more rapid tumour growth with the final result being an overall similarity in the measured tumour volumes in the two groups. Further experiments using antrectomised rats or doses of omeprazole that do not significantly raise gastrin concentrations would be needed to dissociate the effects of the drug itself from those resulting from gastrin. Finally, Graffner et al did not find any effect of omeprazole on the growth of colonic tumour xenografts in mice, ${ }^{18}$ and so inhibitory effects of omeprazole on tumour growth seem unlikely.

Secondly, underfeeding or calorie restriction, or both with reduced weight gain and growth have been shown to inhibit the development of tumours at various sites, including the colon, in animals. ${ }^{30}$ In this study, the omeprazole treated animals did grow more slowly than the vehicle treated rats and were, on average, $12 \%$ lighter at the end of the study. Calculated food intake, measured frequently throughout the experiment (Table I) did not show that rats in the omeprazole group consumed less - in fact food intake was either similar or greater in the omeprazole group at four of five time points measured. These findings of increased food intake but slightly reduced weight gain are consistent with what was noted during the development and testing of omeprazole $^{32}$ although it is not known why it occurs. When the 19 omeprazole rats included in effective numbers for analysis are subdivided into those with tumours $(n=12)$ and those without tumours $(n=7)$ there is no significant difference between their mean weights (MannWhitney U test). Using Spearman's rank correlation coefficient, there is no correlation between

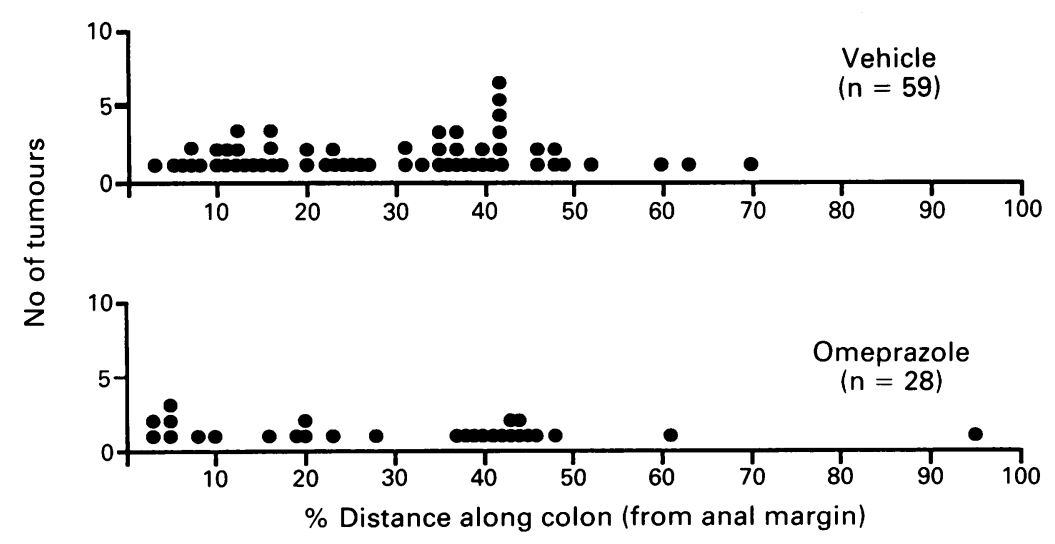

Figure 3: Site distribution of colorectal tumours. Tumour positions are expressed as percentage distance along the length of the colon, from the anal margin $(0 \%=$ anal margin, $100 \%=$ caecum).

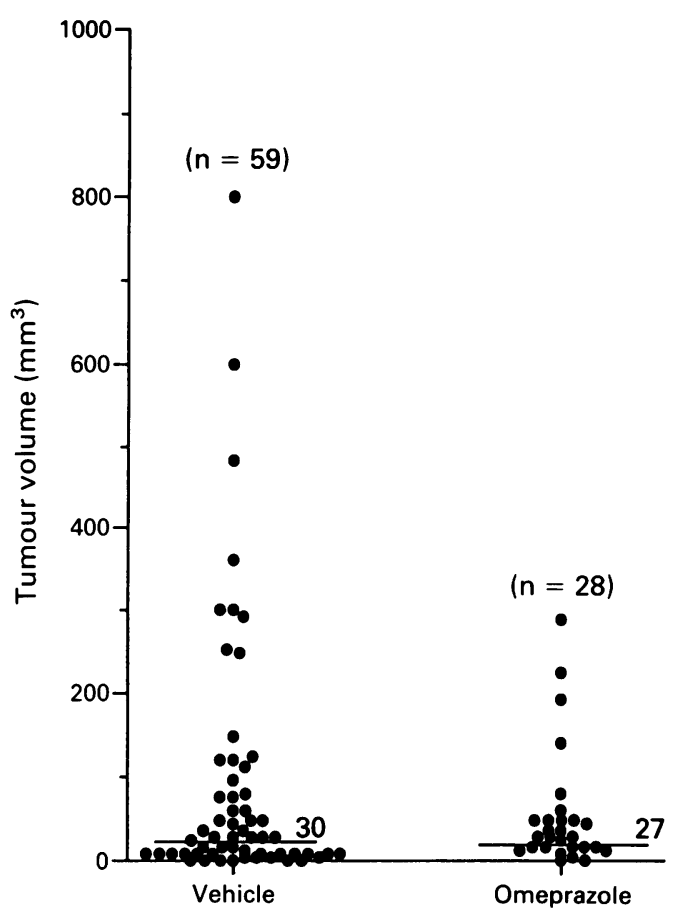

Figure 4: Tumour volumes $\left(\mathrm{mm}^{3}\right)$. Horizontal bar represents the median value in each group.

final weight and the number of tumours per rat $\left(r_{s}=0.195 ; p>0.2\right)$ or between animal weight and the total tumour 'burden' per rat, 'burden' being the total volume of all lesions in that rat $\left(r_{s}=-0 \cdot 149 ; p>0 \cdot 2\right)$. Furthermore, the study of Kumar et al found significant inhibition of azoxymethane induced tumours only at values of calorie restriction of $20 \%$ or more ${ }^{33}$ and from other published data on calorie restriction and experimental carcinogenesis, ${ }^{3031}$ we feel the small weight difference in this study is unlikely to have made more than a minor contribution to our results.

A further possibility for the reduced tumour incidence in the omeprazole group is that the gastrin concentrations were excessively high and may even have inhibited cell growth. The values of gastrin reported to stimulate colonic epithelial proliferation vary greatly. While modest twothreefold rises in gastrin have been found to be trophic, even G-17 concentrations as high as $1600 \mathrm{pmol} / \mathrm{l}$ (equivalent to $3200 \mathrm{ng} / \mathrm{l}$ ) stimulated a colorectal cancer cell line in vitro, although maximum stimulation occurred at lower doses (400 pmol/l - that is, $800 \mathrm{ng} / \mathrm{l}$ ). ${ }^{34}$ Durrant et al also found that the optimum concentration of gastrin for several cell lines was $3 \mathrm{ng} / \mathrm{ml}$ (3000 $\mathrm{ng} / \mathrm{l}$ ) when testing gastric and colorectal cancer cell lines for their trophic responses to added gastrin. ${ }^{35}$ The maximum stimulation of HT29 colon cancer cells in one study occurred in response to $400 \mathrm{pmol} / \mathrm{l}$ of G-17 (equivalent to $800 \mathrm{ng} / \mathrm{l})$ but even a dose of $4000 \mathrm{pmol} / \mathrm{l}(8000$ $\mathrm{ng} / \mathrm{l})$ stimulated growth, albeit to a lesser degree. ${ }^{36}$ In addition, the same authors found that very high doses of pentagastrin (500 and $1000 \mu \mathrm{g} / \mathrm{kg}$ ) stimulated the growth of colonic cancer xenografts in mice. In a study of 31 fresh human colorectal tumours, screened in vitro for their trophic responsiveness to gastrin, ${ }^{37} 17$ of 31 tumours were found to be gastrin responsive, 
most responding maximally to high concentrations of gastrin $(2-50 \mu \mathrm{g} / \mathrm{l}$ - that is, $2000-50000$ $\mathrm{ng} / \mathrm{l})$. Normal rat colonic epithelium in vivo has been found to respond trophically to doses of pentagastrin ranging up to $1000 \mu \mathrm{g} / \mathrm{kg}$ with a significant quadratic dose response relation, ${ }^{38}$ and a similar dose response relation for gastrin on gastric ECL cells has also been found. ${ }^{39}$ In this study, constant infusions of gastrin were trophic to the ECL cells with the maximum effect occurring at circulating gastrin concentrations of $250-400 \mathrm{pmol} / \mathrm{l}$ (equivalent to $500-800 \mathrm{ng} / \mathrm{l}$, a seven to 11-fold rise in gastrin concentrations compared with control animals). Furthermore, even the highest infusion dose of gastrin, which resulted in a 14-fold rise in serum gastrin concentrations, was trophic to the cells. Thus, the concentrations of gastrin we obtained are similar to those that have previously been shown to be trophic for rat gastrointestinal epithelium.

The gastrin concentrations in our rats were also similar to those that may be seen during chronic omeprazole treatment in humans. While most patients have three to fourfold rises in serum gastrin, in the study by Jansen et al 8 of 32 patients during longterm omeprazole treatment had fasting gastrin values of over $500 \mathrm{ng} / \mathrm{l}$, which was more than 10 times the median value. ${ }^{40}$ Bearing in mind that the postprandial rise in gastrin is maintained during omeprazole treatment, their postprandial values would be more than $1000 \mathrm{ng} / \mathrm{l}$. Furthermore, pernicious anaemia patients may have gastrin concentrations of around $2000-4000 \mathrm{ng} / \mathrm{l} .{ }^{41}$ Thus, we feel that the hypergastrinaemia produced in this study is relevant to the values seen clinically in patients with pernicious anaemia and also during omeprazole treatment.

As none of the above explanations satisfactorily accounts for the reduced tumour prevalence in the omeprazole group, an effect of omeprazole itself on the carcinogenic process must be considered. Longterm treatment with acid inhibitory drugs has been shown to result in bacterial overgrowth in the upper gastrointestinal tract, ${ }^{42}$ changing the composition of the intestinal microflora. Such bacteria may be important in colonic carcinogenesis and contribute to the tumourigenicity of azoxymethane, ${ }^{43}$ possibly by participating in metabolism of the carcinogen in the colon. It is conceivable that the omeprazole effect on colonic carcinogenesis was secondary to the drug affecting the composition and enzymatic activity of the intestinal microflora and thereby changing the metabolism of the carcinogen.

Alternatively, omeprazole may have exerted its effects by modifying the metabolism of azoxymethane by the liver or intestinal mucosa. Most known carcinogens exist as procarcinogens and require metabolic activation, usually by hydroxylation, in the liver to exert their genotoxic effects ${ }^{44}$ and these reactions are carried out by members of the cytochrome P450 supergene family of enzymes. ${ }^{46}$ Cytochromes P450 IA1 and IA2 have been found to be the main ones participating in the metabolic activation of a variety of carcinogens including numerous heterocyclic amines commonly present in cooked food ${ }^{4748}$ and polycyclic aromatic hydrocarbons. The levels of expression of these enzymes, and their activities, both in the liver and also in extrahepatic tissues such as small intestine and colon can be modified by various factors. These include dietary lipid, ${ }^{49}$ extracts of cruciferous vegetables, ${ }^{50}$ and xenobiotics including other carcinogens. ${ }^{5152}$ It is possible that the comparative expressions of these, and other, P450 enzymes in different tissues may be important in determining the overall balance between activation and detoxification of a given xenobiotic and its carcinogenic effectiveness. Cytochrome P450 enzymes capable of metabolising azoxymethane have also been found in the colon of humans and animals. ${ }^{53-55}$ While cytochrome P450 IIEl seems to be important in the activation of azoxymethane, ${ }^{56}$ the full pathway of azoxymethane metabolism has not been elucidated and the role of other cytochrome P450 enzymes, notably cytochrones P450 IA1 and IA2 remains to be determined.

Omeprazole has been shown to interact with the cytochrome P450 system. In 1990, Diaz et $a l^{57}$ showed that omeprazole was a potent inducer of both cytochromes P450 IA1 and IA2 in human hepatocytes in vitro (although no effect with cytochrome P450 IIEl was noted) and raised fears that this may result in increased activation of carcinogens metabolised by these enzymes. Subsequently the newer $\mathrm{H}+/ \mathbf{K}+$ ATPase inhibitors, pantoprazole and lansoprazole, have also been found to modulate cytochrome P450 enzyme activity in animals. ${ }^{58}$ Furthermore, in biopsy specimens from human volunteers, McDonnell et al ${ }^{59}$ have shown very recently that omeprazole treatment for seven days induced cytochrome P450 IAl gene expression and enzyme activity in vivo in the gastrointestinal mucosa with the most noticeable effects seen in the duodenum. These are probably direct effects of the drug or a metabolite rather than the resulting hypergastrinaemia as continuous infusions of pentagastrin do not seem to affect cytochrome P450 enzyme activity, at least in the small intestine..$^{60}$

These findings and the concerns expressed about omeprazole have proved controversial and stimulated much debate. ${ }^{61-64}$ While it seems logical to assume that induction of cytochrome P450 IA proteins, with increased activation of heterocyclic amines and increased mutagenicity, would result in enhanced carcinogenicity, this has not been found to be the case when studied in animal models of cancer development. Indeed the contrary has been found to be the case, with induction of IA proteins being repeatedly shown to be associated with protection against tumour formation. ${ }^{65-67}$ Similarly, inhibition of these enzymes is associated with enhanced carcinogenesis in animals, ${ }^{68}$ despite the reduced activation of the carcinogens under study. Thus, showing increased carcinogen activation and mutagenicity in vitro on the one hand does not necessarily correlate with increased tumour formation. In fact, the opposite seems to apply, highlighting our relative lack of understanding of this extremely complex subject.

The reduced carcinogenic activity of azoxymethane during omeprazole treatment may be related to omeprazole modifying the metabolism 
of the carcinogen in the colon or liver or affecting P450 isoenzymes differentially at these two sites. Further studies on both the pathway of azoxymethane metabolism and the effects of omeprazole on this pathway are obviously needed before conclusions can be made regarding the mechanism(s) by which omeprazole exerts its protective effects. For instance, it is not known whether the omeprazole inducible enzymes, IA1 and IA2, are important in azoxymethane metabolism.

Because of the unexpected inhibitory effects of omeprazole on colorectal carcinogenesis, the present model is unsuitable for assessing the effect of chronic hypergastrinaemia on colonic carcinogenesis. Chronic hypergastrinaemia as a result of other causes, however, cannot be excluded from having an important part in colorectal cancer development. This study does suggest that fears regarding the potential deleterious effects of omeprazole on carcinogenesis ${ }^{5759}$ may be unfounded. Further studies on the mechanism(s) by which omeprazole protects against chemical colorectal tumourigenesis and the doses at which this occurs are merited and may shed light on the pathogenesis of this common disease.

We would like to thank Mr Hugh Shannon and Mr John Lawrie for their expert technical assistance with the animal handling, Mrs Divina Fillmore for help with the gastrin assays, and we recognise the secretarial skill of Mrs Dorothy Ronney. This work was supported by the Biomedical and Clinical Research Committee of the Scottish Home and Health Department and by the Research Support Group of Greater Glasgow Health Board (Grant ref no RSG/SHHD/9293/D).

1 Johnson LR. New aspects of the trophic action of gastrointestinal hormones. Gastroenterology 1977; 72: 788-92.

2 Sirinek KR, Levine BA, Moyer MP. Pentagastrin stimulates in vitro growth of normal and malignant human colon epithelial vitro growth of normal and malignan
cells. Am $\mathcal{F}$ Surg 1985; 149: 35-8.

3 Watson SA, Durrant LG, Morris DL. Growth-promoting action of gastrin on human colonic and gastric tumour cells action of gastrin on human colonic and gast

4 Winsett OE, Townsend CM, Glass EJ, Thompson JC. Gastrin stimulates growth of colon cancer. Surgery 1985; 99: 302-7.

5 Beauchamp RD, Townsend CM, Singh P, Glass EJ, Thompson JC. Proglumide, a gastrin receptor antagonist, inhibits growth of colon cancer and enhances survival in mice. Ann Surg 1985; 202: 303-8.

6 Watson SA, Durrant LG, Elston P, Morris DL. Inhibitory effect of the gastrin receptor antagonist (L-365,260) on gastrointestinal tumour cells. Cancer 1991; 68: 1255-60.

7 Eggstein S, Imdahl A, Kohler M, Waibel M, Farthmann EH. Influence of gastrin, gastrin receptor blockers, epidermal growth factor and difluoromethylornithine on the growth and activity of ornithine decarboxylase of colonic carcinoma and activity of ornithine decarboxylase of colon

8 Singh P, Rae-Venter B, Townsend CM, Khalil T, Thompson JC. Gastrin receptors in normal and malignant gastrointestinal mucosa: age-associated changes. Am $\mathcal{f}$ Physiol 1985; 249: G761-9.

9 Upp JR, Singh P, Townsend CM, Thompson JC. Clinical significance of gastrin receptors in human colon cancers. Cancer Res 1989; 49: 488-92.

10 McGregor DB, Jones RD, Karlin DA, Romsdahl MM. Trophic effects of gastrin on colorectal neoplasms in the rat. Ann Surg 1982; 495: 219-23.

11 Oscarson JEA, Veen HF, Williamson RCN, Chir B, Ross JS Malt RA. Compensatory postresectional hyperplasia and Malt RA. Compensatory postresectional hyperplasia and starvation atrophy in small bowel: dissociation from end
genous gastrin levels. Gastroenterology 1977; 72: 890-5.

12 Williamson RCN, Bauer FLR, Oscarson JAE, Ross JS, Malt RA. Promotion of azoxymethane-induced colonic neoplasia by resection of the proximal small bowel. Cancer Res 1978; by: $3212-7$.

13 Karlin DA, McBath M, Jones RD, Elwyn KE, Romsdahl $M M$. Hypergastrinaemia and colorectal carcinogenesis in the rat. Cancer Lett 1985; 29: 73-8.

14 Aspegren K, Eriksson S, Leidberg G, Trope C. In vitro responsiveness of human gastric carcinoma to pentagastrin Scand F Gastroenterol 1977; 12: 253-6.

15 Oscarson J, Hakanson R, Liedberg G, Lundqvist G, Sundler F, Thorell J. Variated serum gastrin concentration: trophic effects on the gastrointestinal tract of the rat. Acta Physio Scand 1979; 475 (Suppl): 1-18.

16 Oscarson JAE, Veen HF, Ross JS, Malt RA. Dimethylhydrazine-induced colonic neoplasia: dissociation from endogenous gastrin levels. Surgery 1982; 92: 525-30.
17 Tatsuta $M$, Yamamura $H$, Iishi $H$, Noguchi S, Ichii $M$, Taniguchi $\mathrm{H}$. Gastrin has no promoting effect on chemically induced colonic tumours in Wistar rats. Eur $\mathcal{F}$ Cancer Clin Oncol 1985; 21: 741-4.

18 Graffner H, Singh G, Chaudry I, Milsom JW. Omeprazoleinduced hypergastrinemia does not influence growth of colon carcinoma. Dig Dis Sci 1992; 37: 485-9.

19 Palmer-Smith J, Wood JG, Solomon TE. Elevated gastrin levels in patients with colon cancer or adenomatous polyps. Dig Dis Sci 1989; 34: 171-4.

20 Wong K, Beardshall K, Waters CM, Calam J, Poston GJ Postprandial hypergastrinaemia in patients with colorectal costprandial hypergastrinaem

21 Charnley RM, Thomas WM, Stanley J, Morris D. Serum gastrin concentrations in colorectal cancer patients. gastrin concentrations in colorecta
Ann $R$ Coll Surg Engl 1992; 74: 138-41.

22 Seitz J-F, Giovannini M, Monges G, Sauvan R, Wartelle C, Martin P. La gastrinemie dans les cancers colorectaux. Gastroenterol Clin Biol 1992; 16: 385-7.

23 Baldwin GS, Zhang Q-X. Measurement of gastrin and transforming growth factor-alpha mRNA levels in colonic carcinoma cell lines by quantitative polymerase chain reaction. Cancer Res 1992; 52: 2261-7.

24 Watson SA, Durrant LG, Wencyk PM, Watson AL, Morris DL. Intracellular gastrin in human gastrointestinal tumour cells. I Natl Cancer Inst 1991; 83: 866-71.

25 Sharma BK, Walt RP, Pounder RE, Gomes MFA, Wood EC Logan LH. Optimal dose of oral omeprazole for maximal 24 Logan LH. Optimal dose of oral omeprazole for maximal 24

$26 \mathrm{Havu}$ N. Enterochromaffin-like cell carcinoids of gastric mucosa in rats after life-long inhibition of gastric secretion Digestion 1986: 35: 42-55.

27 Pawlikowski M, Wajs E, Lewinski A, Szkudlinski M, Rybicka I, Sewerynek E. Effect of omeprazole-induced hypergastrinaemia on the proliferation of colonic mucosal epithelial cells in the rat. Exp Clin Edocrinol 1991; 97: 50-4.

28 Ardill JES. Radioimmunoassay of GI hormones. Clin Endocrinol Metab 1979; 8: 265-80.

29 Sunter JP, Appleton DR, Wright NA, Watson AJ. Pathological features of the colonic tumours induced in rats by the administration of 1,2-dimethylhydrazine. Virchows Arch [B] 1978; 29: $211-23$.

30 Kritchevsky D. Influence of caloric restriction and exercise on tumorigenesis in rats. Proc Soc Exp Biol Med 1990; 193: 35-8.

31 Albanes D. Total calories, body weight, and tumor incidence in mice. Cancer Res 1987; 47: 1987-92.

32 Ekman L, Hansson E, Havu N, Carlsson E, Lundberg C. Toxicological studies on omeprazole. Scand $\mathcal{F}$ Gastroenterol 1985; 20: 53-69.

33 Kumar SP, Roy SJ, Tokumo K, Reddy BS. Effect of different levels of calorie restriction on azoxymethane-induced colon carcinogenesis in male F344 rats. Cancer Res 1990; 50: 5761-6.

34 Yactayo S, Patrice T, Foultier M-T, Berrada A, Xu XN Influence de la gastrine et de l'enprostil, analogue de la PGE2, sur la croissance de cellules cancereuses coliques. Gastroenterol Clin Biol 1991; 15: 519-24.

35 Durrant LG, Watson SA, Hall A, Morris DL. Co-stimulation of gastrointestinal tumour cell growth by gastrin, transforming growth factor and insulin like growth factor-I. BrF Cancer 1991; 63: 67-70

36 Palmer-Smith J, Solomon T. Effects of gastrin, proglumide, and somatostatin on growth of human colon cancer. Gastroenterology 1988; 95: 1541-8.

37 Watson SA, Durrant LG, Crosbie JD, Morris DL. The in vitro growth response of primary human colorectal and gastric cancer cells to gastrin. Int $\mathcal{F}$ Cancer 1989; 43: 692-6.

38 Fatemi SH, Cullan GE, Sharp JG. Evaluation of the effects of pentagastrin, gastrin and pancreatic glucagon on cell proliferation in the rat gastrointestinal tract. Cell Tissue Kinet 1984; 17: 119-33.

39 Brenna E, Waldum HL. Trophic effect of gastrin on the enterochromaffin like cells of the rat stomach: establishment enterochromaffin like cells of the rat stomach: establish

40 Jansen JBMJ, Klinkenberg-Knol EC, Meuwissen SGM, De Bruijne JW, Festen HPM, Snel P, et al. Effect of long-term treatment with omeprazole on serum gastrin and serum group $A$ and $C$ pepsinogens in patients with reflux esophagitis. Gastroenterology 1990; 99: 621-8.

41 Lamers CBH. Serum gastrin response to feeding in achlorhydric patients. Hepatogastroenterology 1980; 27: $217-9$.

42 Sharma BK, Santana IA, Wood EC, Walt RP, Pereira M, Noone $P$, et al. Intragastric bacterial activity and nitrosation before, during, and after treatment with omeprazole. $B M \mathcal{F}$ 1984; 289: 717-9.

43 Reddy BS, Narisawa T, Wright P, Vukusich D, Weisburger JH, Wynder EL. Colon carcinogenesis with azoxymethane and dimethylhdrazine in germ-free rats. Cancer Res 1974; 35: 287-9.

44 Guengerich FP. Roles of cytochrome P-450 enzymes in chemical carcinogenesis and cancer chemotherapy. Cancer Res 1988 ; 48: 2946-54

45 Snyderwine EG, Schut HAJ, Adamson RH, Thorgeirsson UP, Thorgeirsson SS. Metabolic activation and genotoxicity of heterocyclic arylamines. Cancer Res 1992; 52: 2099-102.

46 Gonzalez FJ, Gelboin HV. Human cytochromes P450: evolution, catalytic activities and interindividual variations in expression. In: Gledhill BL, Mauro F, eds. New horizons in biological dosimetry. Chichester: Wiley-Liss, 1991: 11-20.

47 Turesky RJ, Lang NP, Butler MA, Teitel CH, Kadlubar FF. Metabolic activation of carcinogenic heterocyclic aromatic amines by human liver and colon. Carcinogenesis 1991; 10: 1839-45. 
48 Wakabayashi K, Nagao M, Esumi H, Sugimura T. Food derived mutagens and carcinogens. Cancer Res 1992; 52: 2092-8

49 Yoo J-SH, Smith TJ, Ning SM, Lee M-J, Thomas PE, Yang CS. Modulation of the levels of cytochromes P450 in rat liver and lung by dietary lipid. Biochem Pharmacol 1992; 43: 2535-42.

50 Vang $\mathrm{O}$, Jensen $\mathrm{H}$, Autrup $\mathrm{H}$. Induction of cytochrome P-450IA1, IA2, IIB 1, and IIB2 IIE1 by broccoli in rat liver and colon. Chem Biol Interact 1991; 78: 85-96.

51 Harper PA, Prokipcak D, Bush LE, Golas CL, Okey AB Detection and characterization of the $\mathrm{Ah}$ receptor fo 2,3,7,8-tetrachlorodibenzo-p-dioxin in the human colon adenocarcinoma cell line LS180. Arch Biochem Biophys 1990; 290: 27-36.

52 Kleman M, Overvik E, Mason G, Gustafsson J-A. Effects of the food mutagens MeIQx and PhIP on the expression of cytochrome P450IA proteins in various tissues of male and female rats. Carcinogenesis 1990; 11: 2185-9.

53 Stralka D, Strobel W. Characterisation of cytochrome P450 dependent dimethylhydrazine metabolism in human colon microsomes. Cancer 1991; 68: 2363-9.

54 Rosenberg DW. Specific induction in the carcinogen inducible cytochrome P450 isoform, P450IA1, in colonic epithelium. Arch Biochem Biophys 1991; 284: 223-6.

55 White TB, Hammond DK, Vasquez H, Strobel HW. Expression of two cytochromes P450 involved in carcinogen activation in a human colon cell line. Mol Cell Biochem 1991; 102: 61-9.

56 Sohn OO, Ishizaki H, Yang CS, Fiala ES. Metabolism of azoxymethane, methylazoxymethanol and $\mathrm{N}$-nitrosodimethylamine by cytochrome P450IIE1. Carcinogenesis 1991 12: 127-31.

57 Diaz D, Fabre I, Daujat M, Saunt Aubert B, Bories P, Miche $\mathrm{H}$, et al. Omeprazole is an aryl hydrocarbon-like inducer of human hepatic cytochrome P450. Gastroenterology 1990; 99:
58 Simon WA, Budingen C, Fahr S, Kinder B, Koske M. The $\mathrm{H}+/ \mathrm{K}+-\mathrm{ATPase}$ inhibitor pantoprazole (BY1023/ SK\&F96022) interacts less with cytochrome P450 than omeprazole and lansoprazole. Biochem Pharmacol 1991; 42: 347-55.

59 McDonnell WM, Scheiman JM, Traber PG. Indution of cytochrome P450 IA genes (CYPlA) by omeprazole in the human alimentary tract. Gastroenterology 1992; 103: 1509-16.

60 Pascoe GA, Correia MA. Role of gastrin/pentagastrin in regulation of intestinal cytochrome P450. Comp Biochem Physiol 1988; 90C: 41-6.

61 Farrell GC, Murray M. Human cytochrome P450 isoforms. Gastroenterology 1990; 99: 885-9.

62 Lucier GW, Thompson CL, Hoel DG. Omeprazole, cytochrome P450, and chemical carcinogenesis. Gastroenterology 1992; 102: 1823-4.

63 Parkinson A, Hurwitz A. Omeprazole and the induction of human cytochrome P-450: A response to concerns about potential adverse effects. Gastroenterology 1991; 100: 1157-64.

64 Moldeus P, Berlin RG, Lu A, Castagnoli Jr N, Carlsson E Andersson T. P450/Losec (letter). Gastroenterology 1991; 100: $1488-9$.

65 Anderson LM, Seetharam S. Protection against tumorigenesis by 3-methylcholanthrene in mice by b-naphthoflavone as a

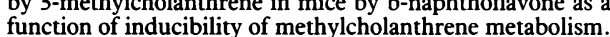
Cancer Res 1985; 45: 6384-9.

66 Miller EC, Miller JA, Brown RR, MacDonald JC. On the protective action of certain polycyclic aromatic hydrocarbons against carcinogenesis by aminoazo dyes and 2-acetylaminofluorene. Cancer Res 1958; 18: 469.

67 Wattenberg LW, Leong JL. Inhibition of the carcinogenic action of benzo[a]pyrene by flavones. Cancer Res 1970; 30: 1922-5.

68 Wheatley DN. Enhancement and inhibition of the induction by 7,12-dimethylbenz[a]anthracene of mammary tumors in female Sprague-Dawley rats. BrF Cancer 1968; 22: 787-97. 